Discourse and Communication for Sustainable Education, vol. 3, pp. 83-99, 2012

\title{
BRANDING THE GREEN EDUCATION: CHALLENGES FACING IMPLEMENTATION OF EDUCATION FOR SUSTAINABLE DEVELOPMENT IN EGYPT
}

\author{
Omar Ramzy and Rasha Wahieb \\ Heliopolis University for Sustainable Development, Egypt
}

\begin{abstract}
Due to the scarcity in natural resources and the demand for green labour and economy, education for sustainable development (ESD) gained a great importance in developed countries, let alone developing ones. From this point of view, this paper is studying the possibility of infusing ESD in Egypt after one and a half years since January 2011 youth revolution. A primary data gathering method was conducted within a sample of 79 young undergraduate people (67 from the American University in Cairo and 12 fresh graduates from conventional educational systems). The results indicated that there is a positive relationship between high cultural resources along with early childhood awareness and ESD adoption and infusion. Also, Spearman's rank association test showed a negative relationship between ESD infusion and the satisfaction level of the current conventional curriculum. On the other hand, Spearman's rank association test showed that $\alpha$ is greater than 0.05; accordingly, there was no correlation between ESD infusion if introduced within the curriculum of an existing well-established university than if introduced as the final outcome of a new university specialised in ESD. The paper highlights the importance of ESD brand associations offered as a service product. After validating the hypothesis, the author discusses the findings and provides solid recommendations for ESD infusion in Egypt.
\end{abstract}

Key words: education for sustainable development, green education, branding, cultural resources

\section{Introduction}

Education for sustainable development (ESD) is the main platform for the new millennium. This paper discusses the diffusion of ESD from a marketing perspective. ESD is both a challenge and an opportunity. It is a challenge to promote ESD due to the limited cultural resources in Egypt as well as in other developing countries. Neither parents nor students would understand the real value of ESD. Nevertheless, the gains and opportunities are more likely to offset the expected difficulties. From a positive angle, different reputable organisations are endorsing ESD. Eventually, this positive global outlook could generate progressive public support and awareness. 
Marketing efforts hand in hand with all other public relation activities would highlight and distinguish ESD from other conventional educational systems. This paper will provide a thorough analysis of the Egyptian education system. The analysis of previous academic studies will identify the literature gap, thus raising the importance of this study. The paper is an empirical analysis that aims to generate a vivid model for ESD adoption in Egypt and other culturally similar countries. The paper is composed of three dimensions: identifying ESD brand elements and investigating these attributes as people processing service type; undertaking a survey to validate our theoretical model and drafting the recommendations of ESD adoption and suggesting future research. Our aim is to elaborate on the most suitable marketing strategy for ESD diffusion. Within this context, a model will be created for enhancing ESD infusion. The practical and theoretical background along with the research methodology will identify the paper limitations. The major objective of this paper is to provide a full-validated model for ESD adoption.

Sustainable development stands for meeting the development needs of present generations without jeopardising the ability of future generations to meet their own development needs. Sustainable development does not focus solely on environmental issues, but broadly captures the different dimensions of development. Traditionally, sustainable development is conceptually considered in terms of three main pillars.

- Environmental sustainability is defined as the ability of the environment to continue to function properly indefinitely. The goal of environmental sustainability is to minimise environmental degradation and to stop and reverse the process that leads to environmental degradation.

- Economic sustainability is defined as the way to achieving economic growth whilst respecting environmental limits, finding ways to minimise damage to the natural world and making use of the earth's resources in a sustainable way.

- Social sustainability is defined as a compilation of actions and efforts to promote development that does not deplete the stock of social and human resources but rather contributes to the enhancement of their potential. The social pillar also refers to the concept of "building sustainable and harmonious communities" (GHK in association with Danish Technology Institute, T., 2008, p. 10).

Education is a prerequisite for promoting the behavioural changes and providing all citizens with the key competences needed to achieve sustainable development. Success in revising unsustainable trends will, to a large extent, depend on high-quality education for sustainable development.

Education and training should contribute to all three axes of sustainable development, namely:

- the social perspective - education and training strengthen social cohesion by investment in human capital;

- the economic perspective - education and training contribute to building a knowledge society based on sustainable economic growth and

- the environmental perspective - education and training are crucial for changes in citizens' behaviour on issues such as consumption, transport, use of sustainable energies, etc. (GHK in association with Danish Technology Institute, T., 2008). 
ESD is a complicated process that requires collaboration of different partners to introduce. ESD is a holistic orientation that necessitates coordination of different stakeholders to ensure environmental preservation as well as social and economic development. An understanding of sustainable development begins in early childhood. The diffusion of ESD is not limited only to universities. Schools, faculties, non-governmental organisations (NGOs), farmers, manufacturers, service providers and others have a vital role for ESD diffusion (Likon, Asunta, Rihtaršič, \& Korže, 2011). ESD is a vision to empower people to meet future challenges. Out of this importance, the United Nations (UN) declared 2005-2014 as the UN Decade of Education for Sustainable Development (DESD). Since education for sustainable development is composed of economic, social, cultural and environmental issues, the United Nations Educational, Scientific and Cultural Organisation (UNESCO) was asked to lead the decade.

Reorienting universities to address sustainable development is essential to equip graduates with the necessary skills, knowledge and sustainability values to meet the future challenges. ESD is multidisciplinary, also including human rights and climate changes. Based on this context, the Reorient University Curricula to Address Sustainability (RUCAS) project was established to assist university staff and management in Egypt, Lebanon and Jordan to infuse ESD in higher education curricula (Stockholm University Institute for International Education, 2011).

In 2008, the Danish Technology Institute and Technopolis group had identified the types of learning and context of ESD curricula (GHK in association with Danish Technology Institute, T., 2008).

- Formal learning occurs within an organised and structured context (for instance, formal education institutions, such as schools, colleges, vocational training institutes and universities) and follows a particular structured design. It typically leads to a formal recognition (diploma, certificate). In those cases, the issues of sustainable development tend to be inserted in the curriculum of the institution.

- Non-formal learning is embedded in planned activities that are not explicitly designated as formal learning, but which contain an important learning element, such as vocational skills acquired at the workplace.

- Informal learning results from daily life activities related to work, leisure, free time, etc. This type of learning is sometimes referred as experiential learning. Generally, it does not lead to certification.

Our assumption is that the full curriculum of ESD should initially be introduced in the Egyptian education system through both public and private universities to ensure infusion. The education system in Egypt is divided into four main categories: public, which refers to schools and universities owned by the government; Azhary, which refers to schools and universities that are owned by the government but provide education on Islamic religious basis; private/language, which are privately owned schools and universities; international, like International General Certificate of Secondary Education and American Diploma. Graduates of Azhary and public schools are not considered a part or even a potential target market for ESD. Pupils enrolled in those schools are barely satisfying their basic necessities. They are called survivors with low financial resources and innovation capabilities. Their personal characteristics make them very loyal to traditional providers/products (Consulting Business Intelligence, 2012). Private education expenses are far beyond the survivors' limited financial ability. Parents who send their 
offspring to other regular private/language schools could afford the private education fees, but would definitely face extreme cognitive hardships to understand ESD core value. The assumption is based on the limited cultural resources in Egypt.

Usually, the middle class segment is psychologically dominating the high uncertainty avoidance range (Hofstede, 1998). This means that the middle class segment avoids taking risks and hates ambiguity. They prefer to buy common or traditional products and depending on their peers, relatives and personal experience for buying high involvement products or fateful products. Based on this analysis, most of the middle class segment prefers traditional private universities. Thus, the diffusion of ESD in Egypt will encounter extreme challenges as perceived by students and parents who are affiliated to private language schools. This assumption is based on launching ESD as a new product for a new university. On the other hand, we would relax this assumption a little if ESD were being introduced as a new programme in an already well-established university like the American University in Cairo (AUC) or the German University in Cairo (GUC).

Nevertheless, if ESD is being introduced as a new programme in existing private universities, students' perception could be more positive than if being introduced in a newly-born university that is specialised in ESD. Based on this assumption, some efforts could be made to attract international school graduates to join ESD in well-established universities.

Advocates could promote ESD as an experience to shed light on its unique competitive advantage and to sharpen its distinguished market position. A potential position could be established on branding the customer experience. Most of international school graduates are targeting the AUC as the crème de la crème university in Egypt. Studies showed that young adults and teenagers are blindly imitating their peers. It is not likely that ESD will flourish in its early stages, but, for sure, there is a wide opportunity for ESD growth. Egypt is facing many environmental challenges and a growing need for practising green economy to ensure social and economic development, particularly after January 2011 revolution. The paper assumes that conventional, vocational, private and public schools and universities lack the essence of ESD (the American University in Cairo, 2012).

\section{Research problem}

Students and parents will face cognitive dissonance to understand the full value of education for sustainable development - a fact that hinders its full diffusion in Egypt. The term 'cognitive dissonance' is used to describe the feeling of discomfort that results from holding two conflicting beliefs. When there is a discrepancy between beliefs and behaviours, something must change in order to eliminate or reduce the dissonance (Kendra, 2012). Referring to this definition, students and parents will face a feeling of discomfort in their beliefs and behaviours to judge on a sustainable education as compared to the traditional conventional education curriculum.

\section{Branding education for sustainable development}

The American Marketing Association (AMA) defines a brand as a name, term, sign, symbol or design, or a combination of them intended to identify the goods and services of one seller or group of sellers and to differentiate them from those of other sellers 
(Lake, 2012). Brand associations and beliefs are deeply rooted in customers' minds. Brands are like people with their own personalities. Brand associations are the attributes or images of the brand. Branding strategies are deeper than the functional or practical part of the brand. Branding is too much into the intangible attributes or characteristics of the brand (Keller \& Lehmann, 2006).

A strong brand creates consumer preference for the product/service behind the brand. It provides increased revenues and market share, increases the company's market value, prevents new competitors from entering the market and creates a unique and differentiated company image.

ESD has different brand associations with different effects on consumers. Freedom, responsibility and passion are the main pillars of ESD brand's associations. From these pillars, other brand associations are likely to evolve, such as nature, energy, community, arts, culture, development, innovation, natural resources, humanities and major environmental issues. Therefore, ESD allows for a holistic orientation for branding the education experience. This experience will be practised through building students' unique personalities as a result of industry internships and community service activities. Thus, we assume that ESD brand associations represent its value proposition that distinguishes its brand personality.

The present paper investigates if brand associations could come from outside the world (McCracken, 1986) to present a meaningful picture or it would be difficult for Egyptians to understand ESD branding themes. The paper assumes that ESD and its tangible and intangible associations represent a cultural meaning and a positioning strategy. As mentioned previously, due to the limited cultural resources in Egypt, it is expected that parents and students will face extreme hardships to understand ESD concept. Thus, the following hypotheses are formulated: (1) high cultural resources are positively correlated with ESD infusion; (2) early childhood awareness increases the possibilities of ESD adoption; (3) there is a positive correlation between ESD diffusion if introduced within the curriculum of an existing well-established university rather than if introduced as the final outcome of a newly-established university; (4) there is a negative relationship between ESD infusion and satisfaction level of current conventional curriculum.

\section{High cultural resources are positively correlated with ESD infusion}

To validate a long-standing marketing concept, Aaker (1999) affirmed that brand personalities and traits are only important if these traits are reflecting customers' personality and characteristics. People like to own and use products that reflect their self-concepts. This has been evident in the statement "we are what we have".

Some areas which have not been investigated yet are related to the education type and its correlation with specific cultural understanding. Another important dimension that the previous literature did not provide is to identify the cultural attributes and the branding elements for promoting education for sustainable development. Needless to say, by identifying the appealing ESD brand associations, all other following tactics will be much easier to carry on. The authors of this study agree with Aaker (1999) that brand image plays a role as a symbolic value and could strongly influence the buyer's choice. 
Customers' values and brand associations are two sides of one coin. Such values, if appropriately understood, will have a great impact on identifying the appealing associations for promoting ESD. Having said that, establishing the fitting ESD brand image would definitely influence purchasing and consumption curves. In fact, desired images and personal status are shaped in early childhood. This paper assumes that if ESD theories and practices are embedded in core curricula at primary schools, it will be well perceived by the target audience. Pupils' personal traits will be anchored around ESD brand salience.

\section{Early childhood awareness increases the possibilities of ESD adoption}

On another note, if ESD is part of a well-established university curriculum, it would be infused easier than if being introduced as a standalone curricula in a new university. It would lead to the hypothesis as related to a positive correlation between ESD diffusion.

There is a positive correlation between ESD diffusion if introduced within the curriculum of an existing well-established university rather than if introduced as the final outcome of a newly-established university

Based on the nature of ESD curricula, it is to be positioned on sophistication, future orientation, progression, culture and fun. This positioning theme is in alignment with ESD branding elements and, at the same time, fits with the characteristics of ESD target audience. Another branding attribute that needs further illustration is people as part of the service factory. Universities, in general, are providing intangible services. People in service factories are embedded in the branding character of any serious service provider (Tschirhart, Christensen, \& Perry, 2005). ESD as a pure intangible product is located at the far end of the service spectrum. Consumers in pure intangible services count more on the service branding attributes prior to purchase and consumption. Depending on branding attributes to evaluate, the service prior to consumption has a rationale point. Services are very hard to evaluate prior to consumption. Therefore, branding elements help customers to expect the service value before consumption (Rao \& Ruekert, 1994). ESD falls within the range of the experience attributes that entail trying the service first to evaluate it after consumption. Some services have the credential attributes that are making it difficult to evaluate the service even after consumption.

\section{Sekem}

Sekem is a hieroglyphic word which means vitality. It is also a very well known Egyptian company for its holistic self-sustained nature. Sekem is composed of diversified companies that represent a solid and integrated supply chain based on sustainability. One of Sekem's strategic business units is Heliopolis University (HU) for Sustainable Development. HU is introduced in the Egyptian market as part of the Sekem group. Based on Sekem's success and achievements in addressing sustainable development challenges, Heliopolis University will be positioned as an extension for Sekem brand associations. Thus, Sekem will form co-branding alignment with HU to utilise another market opportunity represented in ESD (Rao \& Ruekert, 1994). Sekem and HU co-branding is a pure example of intangible complimentary offers based on relevant brand associations. It is wise to establish co-branding only if the offers are relevant and fitting with each other. This scenario is best described by referring to IBM and Intel co-branding strategy. Sekem 
and HU co-branded strategy is relevant and makes the most sense since both are addressing sustainability but from different dimensions. Sekem is offering tangible real goods, such as organic foods, and it is contributing positively to the society and community through various developmental projects. Whereas HU provides ESD services, so both are very well associated together. Based on this assumption, co-branding might also foster the infusion of ESD in developing countries.

A valid reason for co-branding in general and for ESD particularly is when a second brand is needed to signify quality (Rao \& Ruekert, 1994; Park, Jun, \& Shocker, 1996). If the new brand attributes are not sufficient to convey the brand meaning or to deliver the quality promised, then co-branding is one option to signify value and quality and thus satisfaction. Based on the previous discussion, the following hypothesis is addressed: There is a negative relationship between ESD infusion and satisfaction level of current conventional curriculum.

As mentioned previously, ESD is a hard to grasp concept in limited cultural resource societies; hence, co-branding with a well-established meaningful brand could facilitate the launching process and convey the brand promise. The point is to reduce consumers' cognitive dissonance especially in information processing service. Co-branding strategy is one solution for handling customers' anxiety or concerns. Also brand alliance is crucial when partners face scarce resources. As a matter of fact, resources are not limited to tangible resources but intangibles as well. An unknown brand is a resource deficiency that needs to be complimented by being affiliated to a strong brand (Tschirhart, Christensen, \& Perry, 2005). Universities could overcome ESD brand deficiency by partnering with stakeholders and institutions that are well perceived in sustainable development or are highly ranked in any other related field.

On another note, ESD is a people processing service; therefore, university employees are part of the final output. In order to maximise the final output, employees as administrators and faculty members must buy into the norms and principles of sustainable development. It is a matter of being holistically committed to the ESD marketing promise. The more the service is located at the far end of the intangibility spectrum, the more the personnel will represent a big portion in the service brand (Bateson, 1995; Riley, 2000).

\section{Theoretical framework}

The main objective of this paper is to identify the most influential independent variables which impact ESD infusion in Egypt and to identify the impact of the demographic structure as a moderating variable on ESD adoption. Based on the statistical measures, the researchers aim to validate the hypothesis.

The initial model includes four independent variables (high cultural resources; ESD early childhood awareness; ESD embedded curriculum in a well-established university; education satisfaction) and a demographic component (age, gender, education level, income level and internet literacy). The dependent variable is the acceptance and the infusion of ESD in Egypt. The authors conducted an empirical study to investigate the validity of the model. Based on the secondary sources and empirical data gathering, the final model is provided (Figure 1). 


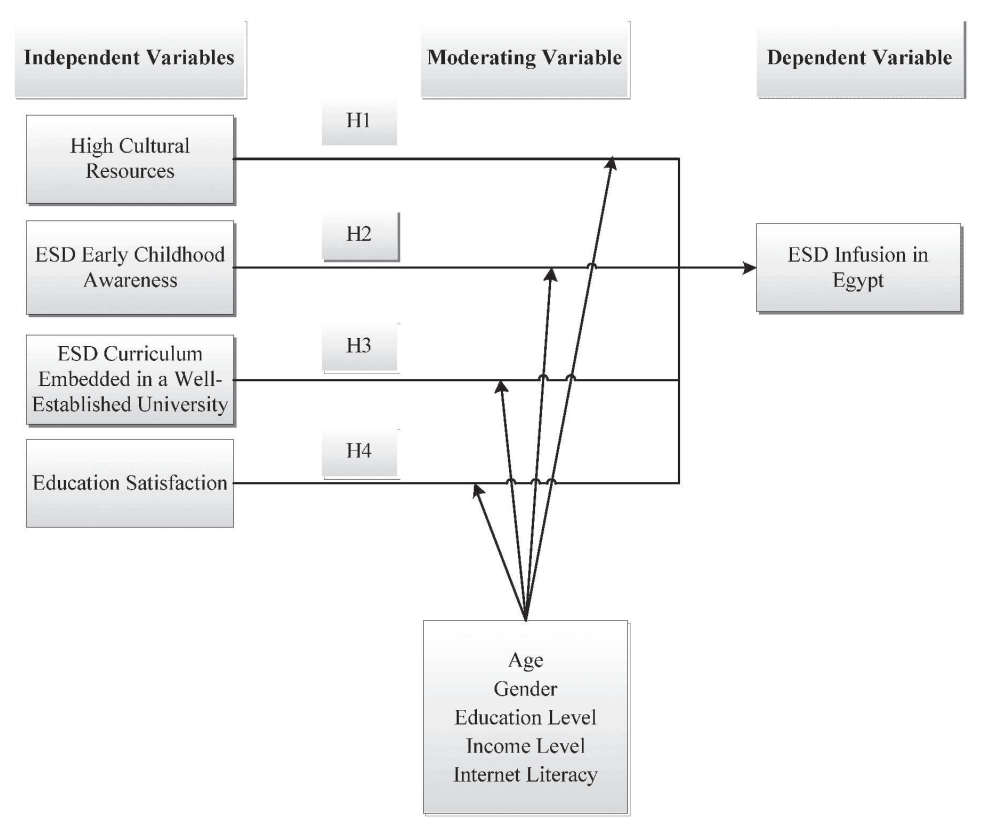

Figure 1. The proposed model

\section{Importance of education for sustainable development infusion}

Our economic activities led us to face unprecedented challenges. These challenges exceeded the environmental spectrum to assault our personal health. Tremendous threats as indicated by the multiple financial and economic crises prove that the conventional economic models are vulnerable and weak (International Greening Education Event, 2011). No doubt that ESD is the most promising path to utilise the limited global resources and to generate green labour generations. Yet, the constraints faced to promote ESD may hinder its adoption. Hence, the authors aim to reach the following objectives: identifying existing and potential bottlenecks for ESD adoption in the Egyptian education system; identifying the target market for ESD; sorting ESD competitive advantages; indicating the most appropriate marketing tactics to deal with threats and opportunities facing ESD providers and providing a concrete model for ESD infusion.

The analytical part of the paper focuses on identifying the threats and the limitations for infusing ESD in Egypt. It specifically focuses on the investigation of the infusion of ESD in private universities. The questionnaire measures students' perception if ESD is to be introduced as part of current university curricula or offered by a specialised ESD university.

\section{Method and sample}

The data is gathered through primary data collection method in which the snowballing and the judgmental sampling approaches were used. A questionnaire was used as the only data collection instrument. Only quantitative close-ended questions were utilised to obtain the results. Validity of the questionnaire was tested with Cronbach's alpha, 
using Statistica Package for the Social Sciences (SPSS). The hypotheses and the proposed model were validated using Spearman's rank association test and ANOVA test.

The chosen sampling method was non-probability sampling, using the snowball technique as the most appropriate to the given research conditions. The students' database of the AUC in Cairo represented the main sample frame. Elder generations were included in the study by using the judgmental sampling approach. The chosen sampling method was non-probability sampling, using the snowball technique as the most appropriate to the given research conditions. The sample size is 79 young people (67 AUC undergraduates and 12 fresh graduates from conventional education systems). The sample includes $62 \%$ females and $38 \%$ males. $70 \%$ of the respondents are younger than 24 years. It should be noted that most of the respondents have either no previous knowledge or a very basic knowledge of ESD.

\section{Education satisfaction and ESD}

The results indicated that $80 \%$ of the satisfied students prefer to study ESD in wellestablished universities and $41.1 \%$ of the satisfied students are willing to specialise in ESD in their current universities. Moreover, $25 \%$ of the satisfied students are willing to continue studying ESD at the postgraduate level. As for the unsatisfied students, $65 \%$ of them prefer to study ESD in a well-established university, and $87 \%$ of the unsatisfied students are willing to specialise in ESD in a well-established university. Also, $78.3 \%$ of the unsatisfied students are willing to continue ESD at the postgraduate level. As for ESD quality, $59 \%$ of the satisfied students believe that well-established universities will ensure ESD, and $51 \%$ of the unsatisfied students felt the same. However, $73.9 \%$ of the unsatisfied students are willing to join a new university specialised in ESD compared to only $35.7 \%$ of the satisfied students. And this brings us to the opportunity available in the higher education market for new universities to enter with the specialty of sustainable development as its core programme.

Heliopolis University (HU) for Sustainable Development - the first non-profit university in the Middle East declaring sustainable development as its overall guiding principle and specialisation. It is based on a renewed understanding of the university concept, in which teaching, research and practice are integrated with each other. What differentiates it from other universities is its vision for sustainable development through empowering students to create new ideas that meet fertile ground for further research and teaching.

As previously mentioned, the curriculum of a university with an ESD context has to be different. In HU, both core and specialist programmes were developed according to the streams related to sustainable development, which are engaging in context, raising consciousness, assimilating content, making a contribution (www.hu.edu.eg).

The core programme includes the four streams: nature and community (balancing inner and outer nature through discovering deep ecology, philosophy and psychology); social sciences (widening knowledge through learning about politics, human rights and social research); the arts (deepening personal development through engaging in music, acting and speech, eurhythmy and fine arts); languages, communication and enterprise (understanding cultures through studying English, German and Arabic (www.hu.edu.eg/).

Incorporating the importance of branding in ESD, HU depended on the three pillars of sustainable development by designing a curriculum that reflects social, economic and environmental perspectives, not only the traditional curriculum of conventional universities. 


\section{Education category and ESD}

Both private and public school students prefer to enrol in a well-established university for learning ESD, but it is apparent that the number of private school students who prefer a well-established university surpasses the number of public school students $177.8 \%$ compared to $57.1 \%$ ). On another note, $13.9 \%$ of private school students prefer to join new universities specialised in ESD, compared to $0 \%$ of public school students. Also, a very small portion of private school students $2.8 \%$ did not indicate that well-established universities would encourage ESD in a more sophisticated way in comparison with new universities specialised in ESD. As for the public school students, $42.9 \%$ did not see that either. Public school students who indicated their interest to join a new university specialised in ESD reached $57.2 \%$ as compared to $45.9 \%$ of private school students. $54.4 \%$ of private school students accepted the idea of continuing the studies on ESD in their current universities, compared to $85.8 \%$ of public school students.

\section{Gender and ESD}

In general, it seems that females are more open to ESD than males. Comparing males and females' attitude towards ESD, we found that $90 \%$ of males prefer to study ESD in a well-established university, and $76.7 \%$ of them indicated that well-established universities will encourage ESD. This finding has a direct impact on their decision to join a new university that specialises in ESD. Whereas $30 \%$ of them decided that they would not join a new university for obtaining ESD, even in their current universities.

On the other hand, females are more open to studying ESD in both well-established and new universities. The percentage of females who prefer to study ESD in wellestablished universities reached $67.3 \%$. Only $44.9 \%$ of the females think that wellestablished universities are better than new universities specialised in ESD. Thus, only a small percentage $(14.3 \%$ ) would refuse to join a new university specialised in ESD. On another note, $63.3 \%$ of females are accepting ESD, and $44.9 \%$ of females would continue postgraduate studies in ESD.

\section{High culture resources and ESD}

The results indicate that there is a positive relation between high culture resources and the tendency to select a well-established university offering ESD. Moderate cultured participants indicated that they might join a new university specialised in ESD.

\section{Reliability analysis}

According to Weiss (2011), there will be an excellent internal consistency of the scale components if the reliability test outcome is .90 and above, high internal consistency if the outcomes are between .90 and .70 , moderate internal consistency if the outcomes are between .70 and .50 and low internal consistency if the outcomes are below .50 . Table 1 shows that all variables of the model are of moderate to high internal consistency. 
Table 1. Results of reliability test

\begin{tabular}{lcc}
\hline \multicolumn{1}{c}{ Variable } & Cronbach's alpha & Number of items \\
\hline Early childhood awareness & .760 & 4 \\
\hline University establishment & .531 & 2 \\
\hline Education satisfaction & .575 & 2 \\
\hline High cultural resources & .506 & 5 \\
\hline ESD adoption and infusion & .501 & 3 \\
\hline
\end{tabular}

\section{Hypothesis validation}

\section{H1. High cultural resources are positively correlated with ESD infusion}

H01 is rejected, and H1 has been accepted since Spearman's rank association test shows a positive relationship between high cultural resources and ESD adoption and infusion; the relation strength is shown by the correlation coefficient 0.310 with a very high significance as $\alpha$ is less than 0.01 (Table 2).

\section{H2. Early childhood awareness increases the possibilities of ESD adoption}

$\mathrm{H} 02$ is rejected, and H2 has been accepted since Spearman's rank association test shows a positive relation between early childhood awareness and ESD adoption and infusion; the relation strength is shown by the correlation coefficient 0.242 with a very high significance, as $\alpha$ is less than 0.05 (Table 2).

H3. There is a positive correlation between ESD infusion if introduced within the curriculum of an existing well-established university rather than if introduced as the final outcome of a newly-established university

$\mathrm{H} 03$ is accepted, and H3 has been rejected since Spearman's rank association test shows that $\alpha$ is greater than 0.05 (Table 2).

H4. There is a negative relationship between ESD infusion and satisfaction level of current conventional curriculum

H04 is rejected, and H4 has been accepted since Spearman's rank association test shows a negative relationship between ESD infusion and satisfaction level of current conventional curriculum; the relation strength is shown by the correlation coefficient -0.294 with very high significance as $\alpha$ is less than 0.01 (Table 2).

Based on this Spearman's rank association test results, the model should be altered to be as shown below (Figure 2). 
Table 2. Spearman's rank association test results

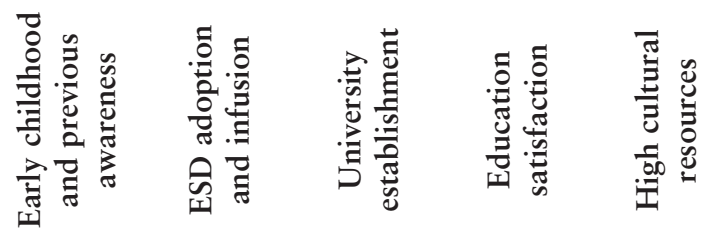

\begin{tabular}{|c|c|c|c|c|c|c|c|}
\hline \multirow{15}{*}{ 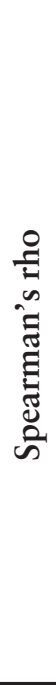 } & \multirow{3}{*}{$\begin{array}{l}\text { Early childhood and } \\
\text { previous awareness }\end{array}$} & C.C. & 1 & $.242 *$ & 0.078 & 0.101 & 0.039 \\
\hline & & Sig. & . & 0.032 & 0.492 & 0.378 & 0.735 \\
\hline & & $\mathrm{N}$ & 79 & 79 & 79 & 79 & 79 \\
\hline & \multirow{3}{*}{$\begin{array}{l}\text { ESD adoption and } \\
\text { infusion }\end{array}$} & C.C. & $.242 \%$ & 1 & 0.064 & $-.294 * *$ & $.310 * *$ \\
\hline & & Sig. & 0.032 & • & 0.574 & 0.009 & 0.005 \\
\hline & & $\mathrm{N}$ & 79 & 79 & 79 & 79 & 79 \\
\hline & \multirow{3}{*}{$\begin{array}{l}\text { University } \\
\text { establishment }\end{array}$} & C.C. & 0.078 & 0.064 & 1 & 0.085 & $.312 * *$ \\
\hline & & Sig. & 0.492 & 0.574 & • & 0.456 & 0.005 \\
\hline & & $\mathrm{N}$ & 79 & 79 & 79 & 79 & 79 \\
\hline & \multirow{3}{*}{$\begin{array}{l}\text { Education } \\
\text { satisfaction }\end{array}$} & C.C. & 0.101 & $-.294 * *$ & 0.085 & 1 & -0.155 \\
\hline & & Sig. & 0.378 & 0.009 & 0.456 & . & 0.172 \\
\hline & & $\mathrm{N}$ & 79 & 79 & 79 & 79 & 79 \\
\hline & \multirow{3}{*}{$\begin{array}{l}\text { High cultural } \\
\text { resources }\end{array}$} & C.C. & 0.039 & $.310 * *$ & $.312 * *$ & -0.155 & 1 \\
\hline & & Sig. & 0.735 & 0.005 & 0.005 & 0.172 & . \\
\hline & & $\mathrm{N}$ & 79 & 79 & 79 & 79 & 79 \\
\hline
\end{tabular}

*. Correlation is significant at the 0.05 level (2-tailed).

$* *$. Correlation is significant at the 0.01 level (2-tailed).

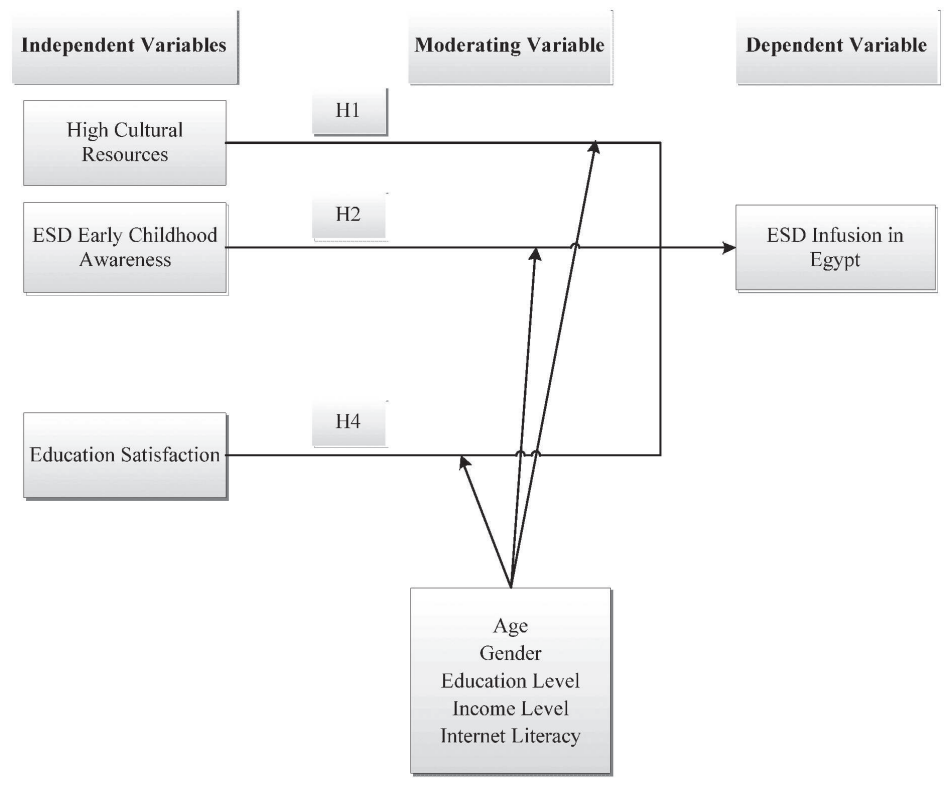

Figure 2. Validated model 


\section{ANOVA Analysis}

ANOVA test results show a valid significance of the model (Table 3). This means that it is not due to a chance.

Table 3. ANOVA test results

\begin{tabular}{clccccc}
\hline \multicolumn{7}{c}{ ANOVA $(\mathbf{b})$} \\
\hline Model & & Sum of squares & df & Mean square & F & Sig. \\
\hline 1 & Regression & 12.279 & 3 & 4.093 & 8.705 & $.000 \mathrm{a}$ \\
\hline & Residual & 35.265 & 75 & 0.47 & & \\
\hline & Total & 47.544 & 78 & & & \\
\hline
\end{tabular}

a. Predictors: (Constant), Early childhood and previous awareness, High cultural resources, Education satisfaction

b. Dependent variable: ESD adoption and infusion

In the model summary, adjusted R square shows that the model explains $22.9 \%$ of the population variations (Table 4 ).

Table 4. Model summary

\begin{tabular}{lccccc}
\hline \multicolumn{5}{c}{ Model summary (b) } \\
\hline Model & $\mathbf{R}$ & R square & $\begin{array}{c}\text { Adjusted R } \\
\text { square }\end{array}$ & $\begin{array}{c}\text { Std. error of } \\
\text { the estimate }\end{array}$ & $\begin{array}{c}\text { R square } \\
\text { change }\end{array}$ \\
\hline 1 & $.508 \mathrm{a}$ & 0.258 & 0.229 & 0.68571 & 0.258 \\
\hline $\begin{array}{l}\text { a. Predictors: (Constant), Early childhood and previous awareness, High cultural } \\
\text { resources, Education satisfaction }\end{array}$ \\
\hline b. Dependent variable: ESD adoption and infusion \\
\hline
\end{tabular}

\section{Discussion}

As the results indicate, the respondents either do not have any previous knowledge about ESD or have a very basic knowledge about it. These findings are very challenging in Egypt since creating awareness about ESD seems like a prerequisite for ESD infusion. Needless to say that ESD infusion would have been much easier if ESD were embedded in school curricula. This relation has been proven as a positive relation between ESD previous knowledge and ESD infusion.

It was expected that satisfied students would prefer to study ESD in a well-established university and to specialise in ESD in their current university. This finding indicates that ESD as a science by itself is acceptable. Also, the results indicated that only $65 \%$ of the unsatisfied students are willing to study ESD in a well-established university compared to $80 \%$ of their satisfied counterparts. The justification is clear since unsatisfied students are more open to obtain ESD in a new university specialised in ESD as they are already dissatisfied with their current university.

Both satisfied and dissatisfied students believe that well-established universities will encourage ESD in a more sophisticated way in comparison with new universities specialised in ESD. $73.9 \%$ of the unsatisfied students are willing to join a new university 
specialised in ESD compared to $35.7 \%$ of the satisfied students. The analysis of these results reveals the following cultural analysis. Egypt is ranked high in the uncertainty avoidance range; thus, people are not risk-takers. Also, Egypt as a developing nation suffered from authoritarian regime for more than 30 years. This is a fact that justifies Egypt's position as a high power distance country. One of the very interesting traits of high power distance societies is that people feel more comfortable to join well-established institutions that have formal rules and regulations to follow; even if these guidelines are not convincing.

On another note, ESD has a potential market share or market equity since $78.3 \%$ of the dissatisfied and $25 \%$ of the satisfied respondents indicated that they would be interested to study ESD in postgraduate studies. Assuming that people understood the basics of ESD, we can confirm that infusing ESD in Egypt is likely to happen without serious challenges. But, still, it is apparent that ESD infusion will face some resistance if it is being introduced in a new university specialised in ESD. To avoid this resistance, new universities should promote high quality of education as it is the number one feature that affects university selection. Results indicate that students prefer being enrolled in ESD programmes offered by well-established universities and not by a new university specialised in ESD. The number of public school students who are willing to join a new university specialised in ESD represented $57.2 \%$. This percentage surpassed the number of private school students $45.9 \%$. However, public school students are not qualified to be included as primary target group for private education enrolment since they cannot afford the university annual tuition. Fortunately, both public and private school students are willing to continue postgraduate studies in ESD.

Females are more open to adopt ESD than males. In general, the results indicated that females are accepting ESD as an idea. Females more than males are willing to join a new university specialised in ESD. Also, the number of males who indicated that wellestablished universities would be better than specialised universities in providing ESD is greater than females. This finding proves again that females are accepting ESD in principle regardless of who is providing it. It proves also that females are more risk-takers than males. Probably females are more open to the nature, environment, arts, culture, community engagement and development than males. However, males and females agree and strongly agree that ESD should be included in school curricula.

Highly cultured people prefer to study ESD in well-established universities. Spearman's rank association test showed a positive relationship between high cultural resources and studying ESD in a well-established university. The relation strength is shown by the correlation coefficient 0.312 with very high significance, as $\alpha$ is less than 0.01 . Highly cultured people think that well-established universities are better in providing ESD than new universities. This means that highly cultured students could be considered as the primary target market for ESD programmes if offered by well-established universities and new universities specialised in ESD as well.

\section{Recommendations}

The most competitive advantage for ESD providers is the quality of education. Both public and private universities should consider the education quality as the most appealing feature for students when selecting a university. The second appealing feature for students is the type of education provided by the university. Needless to say that ESD is considered 
a unique education type that deserves to be highlighted to attract students' attention. Let alone that the type of education is one of the most important features affecting university selection, promoting this new type of education will help promoting the university providing it. The reputation of the university came as the second appealing feature for students. That is why offering ESD in well-established universities is attractive for moderate and highly cultured students. As discussed in the literature reviews section, new universities specialised in ESD should maintain strong affiliations with well-respected brands that are relevant to ESD. Well-established and newly-specialised universities should not emphasise the uniqueness of ESD curricula. Students do not consider the curricula as an appealing feature, and they ranked it as number four. On the contrary, students appreciate the nature and type of education more than the curricula. Based on this finding, it is strongly recommended to emphasise the uniqueness of ESD as a new education type without touching the nature of the courses and the curriculum mechanism.

Universities and other academic institutions must generate appropriate awareness campaigns for infusing ESD. It has been proven that there is a solid correlation between early childhood and previous awareness and ESD infusion. Conventional school graduates are the primary target market for new universities offering ESD in Egypt, not international school graduates. The results indicated that international school graduates are satisfied with their education system and thus aim to continue their education in the same well-established institution. Even among international and other highly ranked private school graduates ESD is mainly being considered if offered by a well-established university, not a new university specialised in ESD. Thus, new universities that specialise in ESD should target conventional school graduates as their primary target market. As for the international school graduates, they are the secondary target market for new universities specialised in ESD.

On the other hand, the primary target market for a well-established university that offers ESD is the international and other upscale school graduates in Egypt. The secondary target market is represented by the conventional school graduates. This should affect private universities specialising in ESD as they should seek funds from organisations caring about the environment to finance scholarships for public school students who have a particular interest in ESD. Moreover, universities should focus on gaining females' attention as a potential target market. This recommendation is for both well-established and new universities. Cultured students are the main target market for ESD. Promoting ESD should take place in cultural centres and other places visited by moderate and highly-cultured students. Libraries and other culture events would be good places for reaching cultured audience. The material used for ESD promotion should give a special attention to ESD as a different type of education, and, at the same time, it should be communicated through cultured communication channels.

\section{Future research}

The same research should be conducted for a larger sample size. A comparison study should be made between Egypt and other countries, especially those that already infused ESD in their curricula. Investigating the launching process that other ESD universities pass through would be an advantage for potential universities. Assessing brand impact on ESD infusion is another future area for investigation. Also identifying the appropriate fit between the education type and its brand associations should be investigated in 
future work. Another relevant topic would be measuring the assumed ESD brand associations to cultured people. It is also important to measure the infusion of ESD in the Middle East and North Africa region as well as the interest of international higher education institutions in partnering with a newly-established university to infuse ESD.

\section{Acknowledgement}

This work has been developed within the framework of the RUCAS (Reorient University Curricula to Address Sustainability) project that has been funded from the European Commission (European Commission, TEMPUS - No. 511118-2010-GR-JPCR). The content of the paper reflects the views of the authors, and the Commission cannot be held responsible for any use which may be made of the information contained therein.

\section{References:}

Aaker, J. L. (1999). The malleable self: The role of self-expression in persuasion. Journal of Marketing Research, 36(2), 45-57. DOI: 10.2307/3151914.

Bateson, J. E. G. (1995). Managing services marketing. London: Dryden Press.

Consulting Business Intelligence. (2012). Retrieved March 5, 2012, from http://www. strategicbusinessinsights.com/vals/presurvey.shtml

GHK in association with Danish Technology Institute, T. (2008). Inventory of innovative practices in education for sustainable development. Brussels: GHK in association with Danish Technology Institute, Technopolis.

Heliopolis University for Sustainable Development. (2012). Retrieved May 5, 2012, from www.hu.edu.eg/

Hofstede, G. (1998). Identifying organizational subcultures: An empirical approach. The Journal of Management Studies, 35(1), 1-12. DOI: 10.1111/1467-6486.00081.

International Greening Education Event. (2011). Retrieved February 5, 2012, from http://www.etechgermany.com/IGEE2011.pdf

Keller, K., \& Lehmann, D. (2006). Brands and branding: Research findings and future priorities. Journal of the Institute for Operations Research and the Management Science, 25(6), 740-759. DOI: 10.1287/mksc.1050.0153.

Kendra, C. (2012). What is cognitive dissonance? Retrieved September 18, 2012, from http://psychology.about.com/od/cognitivepsychology/f/dissonance.htm

Lake, L. (2012). What is branding? Retrieved September 19, 2012, from http://marketing. about.com/cs/brandmktg/a/whatisbranding.htm

Likon, B., Asunta, T., Rihtaršič, T. B., \& Korže, A. V. (2011). Educational partnerships as a way towards quality education for sustainable development and a way towards sustainable society: The case of Slovenia. Canadian Social Science, 7(5), 79-89. DOI: $10.3968 /$ J.css.1923669720110705.045.

McCracken, G. (1986). Culture and consumption: A theoretical account of the structure and movement of the cultural meaning of consumer goods. Journal of Consumer Research, 13(1), 71-84. DOI: 10.1086/209048.

Park, C. W., Jun, S. Y., \& Shocker, A. D. (1996). Composite branding alliances: An investigation of extension and feedback effects. Journal of Marketing Research, 33(4), 453-466. 
Rao, A. R., \& Ruekert, R. W. (1994). Brand alliances as signals of product quality. Sloan Management Review, 36(1), 87-97.

Riley, F. D. (2000). The service brand as relationships builder. British Journal of Management, 11(2), 137-150. DOI: 10.1111/1467-8551.t01-1-00156.

Stockholm University Institute for International Education. (2011). Reorient university curricula to address sustainability. Retrieved April 8, 2012, from www.interped. su.se/pub/jsp/polopoly.jsp?d=16662\&a=97723

The American University in Cairo. (2012). Egypt's burgeoning green economy: The demand for sustainable solutions. Cairo: The American University of Cairo.

Tschirhart, M., Christensen, R., \& Perry, J. (2005). The paradox of branding and collaboration. Public Performance \& Management Review, 29(1), 67-84.

Weiss, N. A. (2011). Elementary statistics (8th edition). New York: Addison Wesley.

\section{Correspondence:}

Dr Omar Ramzy, Assistant Professor of Marketing, Heliopolis University for Sustainable Development, Cairo-Ismailia Desert Road, km 22, Cairo, Egypt. Telephone: +2 01223103919. Email: omar.ramzy@hu.edu.eg 